\title{
Comment
}

\section{Intermodal Transportation and the Freight Forwarder*}

The American system of transport regulation, itself compartmentalized, restricts individual companies to a single mode of transportation -road, rail, air or water. ${ }^{1}$ When a shipment moves by some intermodal combination, responsibility for the job must be divided among several carriers. This may lead to serious problems in coordinating intermodal shipments and can force shippers to use less efficient means of transportation.

The solution most frequently proposed is the creation of so-called "department store" or integrated transportation companies, selling any combination of intermodal services. The railroads, the chief proponents of the integrated transportation company, have long sought permission to diversify into other modes of transportation. They argue that only the intermodal transportation company will permit the shipper to select the most efficient combination of transportation services. "Such coordinated service cannot be supplied by any of the forms of transportation acting independently, nor as a practical matter is it reasonable to

* This student Comment was co-winner of the Israel H. Peres Prize for Volume 76, given for the best student contribution to the volume; the other winner was Judicial Control of Secret Agents, Issue 5.

1. The Interstate Commerce Act requires approval of intermodal mergers or acquisi. tions involving carriers subject to ICC jurisdiction. Relatively more stringent restrictions are placed on rail expansion into other forms of transportation. Section $5(2)$ of the $\Lambda \mathrm{ct}$, 49 U.S.C. $\$ 5(2)(1964)$. The National Transportation Policy requires the Interstate Commerce Commission "to recognize and preserve the inherent advantages of each [mode of transportation]," and to avoid rates which involve "unfair or destructive competitive practices." Declaration of National Transportation Policy, 54 Stat. 899 (1940). In 1959, the Supreme Court ruled that the ICC was required to promote the continued viability of independently-owned modes of transportation. American Trucking Ass'ns v. United States, 364 U.S. 1(1960). See Beardsley, Integrated Ownership of Transportation Companics and the Public Interest, 31 GEO. WASH. L. REv. 85 (1962).

The Federal Aviation Act gives the Civil Aeronautics Board similar powers over surface carrier acquisition or control of air carriers. 49 U.S.C. $\$ 1378$ (b) (1964).

Only the Federal Maritime Commission is not empowered to control entry at all and hence is not involved in the supervision of intermodal competition. Shipping Act of 1916, 46 U.S.C. $\$ \$ 801-42$ (1964); Intercoastal Shipping Act of 1933, 46 U.S.C. $\$ \$ 843.48$ (1964). Water carriers in domestic commerce, other than domestic offshore commerce, are subject to ICG regulation under Part III of the Interstate Commerce Act, 49 U.S.C. \$\$ 901-28 (1964). 
suppose that it could be provided voluntarily through establishment of joint rates and through routes."2

Their opponents rarely meet the issue of efficiency square on. Instead, they normally argue that the stronger mode of transportation-inevitably the railroad-will be able to use its absolutely larger financial resources to obtain a transportation monopoly. 3 The end result will be monopoly profits to the railroads and a reduction in the broad range of services available to shippers under the present system of independent ownership. The most fearful are the motor and barge carriers, who envisage the use of rail-owned carriers as "fighting ships" to channel traffic to the railroads and to drive out independent carriers. While the aviation industry is less afraid of being taken over by rail interests, it argues that the involvement of surface carriers in air transportation will tend to restrict its development.

The substantial integration of the existing regulatory agencies which the integrated transportation company would require is sure to cause additional opposition. It is surprising that these political and administrative barriers to the "department store" carrier have not caused more effort to go into discovering other ways of achieving the benefits of integration. One alternative to the "department store" carrier, little considered in transportation literature, is giving the wholesalers of the transportation industry, the freight forwarders, full freedom to operate in all modes of transportation. In the role of transportation coordinator, the freight forwarder is immune to the principal argument against the integrated transportation company: it does not threaten the survival of non-rail carriers and it does not create the danger of monopoly power. The freight forwarder can provide efficient intermodal service with a much less drastic restructuring of the regulatory framework than that required for the integrated transportation company. Moreover, the freight forwarder primarily serves the shipper who most needs co-

2. Loomis, Common Ownership in Transportation, in Issues iN Trasstorrarro: Econonncs 200, 201 (K. Ruppenthal ed. 1965).

3. This fear of rail domination goes back at least as far as the Panama Canal Act of 1912, which prohibited a railroad from owning, operating, or controlling any imter carrier operating via the Canal or elsewhere with which the railroad was in competition, 49 U.S.C. $\$ 5(14)-(16)(1964)$. For discussion of the purposes and the applications of this Act see Iake Line Applications Under Panama Canal Act, 33 I.C.C. 699, 710-14 (1915).

4. See, e.g., Hearings on Transportation Diversification (H.R. 7960 , etc), BC/ore a Subcomm. of the House Comm. on Interstate and Foreign Commerce, S6th Cong., $2 \mathrm{~d}$ Sess. (1960) [hereinafter cited as 1960 Transport Diversification Hearings]; Special Study Group. National Transportation Policy: Preliminary Draft of a Report Prepared for the Senate Comm. on Interstate and Foreign Commerce, 87th Cong., 1st Sess. 226 (1961); Coordination 4mong Modes of Transportation, 33 ICC PRAC. J. 27 (1965).

5. See 1960 Transport Diversification Hearings 354, 357-58 (Statement of Air Transport issociation of America). 
ordinated intermodal service-the smaller shipper who does not have sufficient market power to "persuade" carriers to handle his shipments in the most efficient manner.

\section{Characteristics of the Freight Forwarder}

A freight forwarder is a common carrier that operates no transportation equipment. ${ }^{\circ}$ This paradoxical definition is based on common law rules governing the liability of carriers to shippers: The courts have consistently ruled that any person who offers to sell transportation to the general public will be treated by the courts as a common carrier. ${ }^{7}$ The freight forwarder comes within these rules because it contracts with shippers for the transportation of property between two points, and then turns around and contracts in its own name with an equipment-operating carrier for the actual shipment of the property. The freight forwarder is commonly termed an "indirect" carrier, while the carriers providing the actual transportation services are "direct" or "underlying" carriers.

Freight forwarders generally handle small shipments; ${ }^{8}$ the largevolume shipper normally buys transportation service directly from the underlying carriers. The forwarder is able to compete with the direct carriers because the direct carriers normally charge less per pound for large than for small shipments. The forwarder consolidates a number of small shipments (bound for the same general area) and ships them together at carload or truckload rates, arranging for the distribution of each individual shipment to its ultimate consignee after arrival at a "break-bulk" point. ${ }^{9}$ In this kind of service, the forwarder's profit comes

6. With the unimportant exception of pickup and delivery cquipment.

7. The history of regulation of the freight forwarder as a common arrier under common law may be found in H. BENNETT, THE CoMmission AND THE COMmoN LAw 25.33 (1964), and Ahearn, Freight Forwarders and Common Carriage, 15 Fordinar L. REv. 248, 252-60 (1946), together with the nineteenth century cases cited in both vorks. Originally, the forwarder was simply an intermediary between the shipper and the carrier, serving as an agent of the shipper to procure transportation for him. When the forvarder came to hold himself out to the general public as a provider of transport services, the courts concluded that he should be treated as a common carricr.

8. The average weight of surface forwarder shipments in 1964 was 464 pounds. It had been as high as 460 pounds at the end of YVorld VVar II, and had slumpcd to 350 pounds by 1958 . The rise since 1958 is probably due to increased forwarder utilintion of traileron-flatcar ["TOFC'] services as a basis for solicitation of larger shipments. ICC, BUREAU OF Transport Economics, Transport Statistics in the United States (PArt 8) (annual) [hereinafter cited as TRANSPORT STATISTICS (PART 8)]. In 1964 the aserage domestic air forwarding shipment was about 40 pounds; the average international air forvarding shipment was about 105 pounds. $\mathrm{CAB}$, Bureau of Operating Rights, Information Exhibit No. 2, p. 2, in Docket 16857, Motor Carrier-Air Freight Forwarder Investigation (1966) [hereinafter cited as Information Exhibit, Docket 16857].

9. Section 402(a)(5) of the Interstate Commerce Act, 56 Stat. 284 (1942), as amended, 49 U.S.C. § 1002(a)(5) (1964), defines a freight forwarder as any person: 
from the spread between the direct carriers' rates for small and for large shipments.

If the forwarder is able to provide better service than the underlying carriers, it may be able to charge a premium for its services, competing with the direct carrier in weight ranges where there is little profit in simple consolidation service. ${ }^{10}$ Alternatively, the forwarder may be able to charge a premium simply because of the benefits to the shipper of single carrier service.

Two pre-1920 Supreme Court decisions prevent the underlying carriers from discriminating for or against freight forwarders. In the later of these, the 1917 Lehigh Valley decision, the Court ruled that the freight forwarder was a shipper in relation to the railroads, and could receive rates no lower than those published by the railroads for other shippers tendering similar shipments. 11 The earlier case prohibited railroads from discriminating against the freight forwarder by treating the forwarder as a dummy and charging it higher rates based upon each separate shipment in the hands of the forwarder. ${ }^{12}$ These two decisions together made it clear that although the freight forwarder is a common carrier in relation to shippers, it is a shipper in relation to the regulated direct carriers. ${ }^{13}$

which ... holds itself out to the general public as a common carrier to transport or provide transportation of property, or any class or classes of property, for compensation, in interstate commerce, and which, in the ordinary and usual course of its undertaking, (A) assembles and consolidates ... shipments of such property, and performs . . break-bulk and distributing operations with respect to such consolidated shipments, and (B) assumes responsibility for the transportation of such property from point of receipt to point of destination, and (C) utilizes, for the whole or any part of the transportation of such shipments, the services of a carrier or carriers subject to Part I, II, or III of this Act.

The CAB regulations provide a parallel definition for air freight forwarders, 14 C.F.R. $\S \S 296.2(\mathrm{a}), 297.2$ (1966).

10. The forwarder may provide better pickup and delivery service, or greater ability to trace shipments and guarantee arrival times. Emery Air Freight, the largest and most profitable air forwarder, charges premium rates for its service. It advertises and apparently succesfully provides ground services superior to those provided by the direct air eirriers or other air forwarders. GAB, Bureau of Operating Rights, Direct Exhibit No. 7, pp. 1-4, in Docket 16857, Motor Carrier-Air Freight Forwarder Investigation (1966) [hereinafter cited as Direct Exhibit, Docket 16857].

11. Lehigh Valley R.R. v. United States, 243 U.S. 444 (1917).

12. ICG v. Delaware, L. \& W.R.R., 220 U.S. 235 (1911). If the forwarder contracted with two different shippers to move a 500-pound shipment for each, and tendered these shipments to the direct carrier as a single 1000-pound shipment, the direct carrier could not treat the shipment for rate-computation purposes as two 500-pound shipments.

13. The doctrine of these cases was extended to other surface and air modes of transportation as they came under regulation, although there was some hesitation in the CAB before applying it. See Airfreight Forwarder Investigation, 21 C.A.B. 536, 558.59 (1955) (allowing preferential rate agreements), and supplemental opinions to this decision at 23 C.A.B. 376 (1956), 24 C.A.B. 755, 757.58 (1957) (on reconsideration, disallowing preferential treatment). In the 1957 opinion, the $C A B$ ruled that there was no evidence that Congress, in providing for indirect air carrier regulation, had intended to change the 


\section{The Freight Forwarder as a Means of Transportation Integration}

In the search for more efficient allocation of transportation resources, the forwarder's great advantage is its ability, on a small capital investment, to offer the "department store" service advocated so strongly by the proponents of direct carrier diversification. ${ }^{14}$ There are no inherent limitations on the choice of routes and transportation modes that it can provide for shippers. An integrated direct carrier, operating on a similar scale, would represent a concentration of economic power that would dwarf the largest American railroads.

Moreover, the forwarder caters primarily to the smaller shipper, who finds it most difficult to determine and obtain the most economical transportation mix. The high volume shipper typically can afford to maintain his own traffic management staff: he will have the economic muscle (in many cases through his ability to resort to private carriage) to bring recalcitrant direct carriers to "understand" his transportation requirements. The freight forwarder can supply both the expertise in traffic management and the economic muscle which the small shipper lacks.

On the other hand, the forwarder is unlikely to have appreciable market power vis-à-vis individual shippers. Insignificant capital requirements make it easy to enter freight forwarding. ${ }^{15} \mathrm{~A}$ one-railroad town with too little freight volume to justify an additional direct rail carrier may be able to support several forwarders. ${ }^{16}$

A further advantage of intermodal freight forwarder service stems from the forwarder's indifference to the relative fortunes of the various modes of transportation. At present, non-rail carriers fear that the railroads, if allowed to expand into other forms of transportation, would conduct non-rail operations solely or primarily for the purpose of increasing rail traffic, and would hinder the technological and economic development of non-rail transport. ${ }^{17}$ The forwarder does not have sunk

traditional rule that, for rate regulation purposes, freight forwarders are to be treated as shippers in relation to direct carriers.

The extent to which the doctrine of these cases applics to maritime transportation is unclear. See p. 1385 infra.

14. See 1960 Transport Diversification Hearings 91, Statement of Alfred E. Perlman, President of the New York Central Railroad: "A true transportation company could offer its customers the best service its management could devise . . . The service would be tailored to meet the needs of the customer-in terms of speed, flexibility, handling, and of cost."

15. Forwarder investment in plant and equipment is discussed infra at notes 68.73, and pp. 1375-76.

16. The 1966-67 New Haven telephone directory lists at least ten ICC-regulated surface forwarders-all serving a town itself served only by a limping, bankrupt railroad.

17. See, e.g., Beardsley, supra note 1; 1960 Transport Diversification Hearings 359. 
costs in transportation right of way and long-lived equipment. Because forwarder investment requirements are not closely related to any particular mode of transportation, the forwarder will be without a financial stake in any particular mode. ${ }^{18}$ Naturally, the forwarder will be attracted to the transportation service where profit margins are greatest. But rate competition among forwarders, coupled with the shippers' pressure for satisfactory service standards, should make fortvarder bias toward any mode of transportation short-lived.

The forwarder, one may presume, will also be better informed than the small or infrequent shipper about the quality of service performed by competing direct carriers, and will be under competitive pressure to obtain the best possible service from direct carriers. No doubt the small shipper eventually discovers the inadequacies of a given direct carrier, but the adjustment process is slower and the pressure upon the carrier less effective.

The freight forwarder can also play an important role in the growth of container services. ${ }^{19}$ Containers compatible for use by different modes of transportation minimize the cost of transferring cargo between transportation modes-an expense that at present cuts deep into the savings of efficient intermodal combinations of carriers. As containerization replaces conventional methods of freight handling, intermodal service becomes relatively more efficient, and a wider market appears for the coordinating services of the intermodal freight forwarder.

Some surface forwarders are already deeply engaged in container or TOFC ("trailer-on-flatcar") operations. ${ }^{20}$ The great pressure, however, on conventional methods of transportation will come when containership services begin on a large scale. ${ }^{21}$ Once containerships are operational, forwarders at inland points will be able to accept trailer-load shipments or to consolidate individual shipments into trailer-loads, and through container service will be available from inland United States

18. A forwarder may have an investment of some size in containers or trailers for TOFC service. But containers are the antithesis of bonds to a particular mode of transportation.

19. This is not the place for extended discussion of the various forms of container service available at present or in the near future. It does secm clear, hovever, that containers provide the most promising tool for obtaining the maximum gains from intermodal coordination. Lichtenstein, Container Age Is Coming Near, Internationsi Commence, December 6, 1955, at 2-8.

20. United States Freight Company, the large freight forwarder holding company, has long been an advocate of domestic TOFC service by forwarders. Gumardi, Freight Goes Forwarder with Forgash, ForTuNe, July 1962, at 132-35.

21. Presently, most or all major shipping companies are moving rapidly into the acquisition or construction of ships suitable for container service. See Lichtenstein, stupra note 19; What Comes After Containers, 222 THE EcoNomist 50 (1967). 
points to inland European points, eliminating all enroute handling of cargo. ${ }^{22}$

One crucial problem for international container shipments is achieving "clear allocation of responsibility for each stage of movement" from inland point to inland point. ${ }^{23}$ The simplest way is to have one carrier control the movement of the container from source to destination. ${ }^{24}$ This is a natural responsibility for freight forwarders, which offer single carrier liability over a journey utilizing more than one carrier and mode of transportation. There may be even more scope for the indirect carrier in international commerce than in domestic commerce, because the "department store" integrated direct carrier is bound to run into political stumbling blocks at international frontiers. No European country is likely to face with equanimity the prospect of the PennCentral lines operating extensive motor carrier services within its borders. A freight forwarder, coordinating a shipment from its home base in the United States, is a far less noxious intruder.

\section{The Lack of Uniformity in Present Freight Forwarder Regulation}

The intermodal freight forwarder cannot be expected to emerge without changes in the pattern of forwarder regulation. Today a forwarder must deal with a new agency each time it uses a different mode of transportation. Forwarders which utilize the services of common carriers under ICC regulation are subject to Part IV of the Interstate Commerce Act. ${ }^{25}$ The forwarder shipping via aircraft is an "indirect air carrier" under the jurisdiction of the Civil Aeronautics Board.20 The forwarder operating in the domestic offshore and international maritime trade is under Federal Maritime Commission jurisdiction. ${ }^{27}$ To

22. North Atlantic Container Experiment, Traffic WorLd, October 29, 1966, at 100. United States Freight Company, together with several ocean carricrs in which it has sub. stantial stock holdings, has recently made through container service available from the inland United States to European points, designed to lower transportation costs for small shippers, N.Y. Times, March 7, 1967, at 82, col. 5 .

23. North Atlantic Container Experiment, supra note 22. Both the government-sponsored experimental shipment and the United States Freight operations were hampered by overlapping and conflicting administrative controls, including both transportation and customs regulations.

24. When "one carrier takes full responsibility and the through rate is subject only to division between carriers-you have pretty much the ultimate in a competitive system." Schmeltzer, Container Revolution Termed Inevitable, Traffic WORLD, November 5, 1966, at 26.

25. 49 U.S.C. $\$ \S 1001-22$ (1964).

26. 49 U.S.C. $\$ 1301(3)$ (1964); 14 C.F.R. $\$ \S 296-97$ (1966).

27. The statutes controlling the FMC, supra note 1, do not mention the indirect marl. time carrier. The maritime indirect carrier is, in general, subject to the same regulation as the direct carrier. See Common Carriers by Water-Status of Non-Vessel Carricrs, 6 F.M.B. 245 (1961); 30 Fed. Reg. 1849 (1965) [discussing the indirect carrier by water in relation to an amendment to 46 C.F.R. $\$ 510.22(\mathrm{c})]$; note 61 infra. 
make intermodal freight forwarding an attractive business proposition, the conflicts and cross currents in transport regulation must be eliminated.

\section{The ICC Freight Forwarder}

As one might suspect, forwarders under the jurisdiction of the ICC have the most stringent regulatory burden. ${ }^{28}$ Before anyone can commence forwarder service he must obtain a permit from the ICC, based on a finding that the applicant is "ready, able, and willing" and that the proposed service is "consistent with the public interest and the national transportation policy." 29 Until 1958, forwarder permits were generally available to anyone capable of providing forwarder service.30 In 1957, however, Congress in effect deleted from the original freight forwarder act a provision which had prohibited the ICC from denying a permit solely on the grounds of competition with other forwarders. ${ }^{31}$ This was interpreted by the Commission as a license to deny new permits solely on the grounds of competition with existing forwarders. Since 1958, the ICC has "found it incumbent in determining applications for freight forwarder authority to make a subsidiary finding as to whether existing service is adequate to meet the evident needs of the supporting shippers." 32 Today forwarder entry is all but impossible

28. Hereinafter the forwarder subject to ICC regulation will normally be termed a "surface forwarder." Forwarders subject to the ICC are defined in the Act as indirect carriers who utilize for the transportation they sell the services of common carriers-rail, road or water-regulated by the ICC. 49 U.S.C. \$ 1002(a)(5) (1964).

29. 49 U.S.C. $\& 1010$ (c) (1964). The surface forwarder permit does not normally grant unlimited geographic operation rights. In 1957, only five of eighty-nine formarders holding permits were authorized to serve all points in the continental United States, although six more served all states from specified origins. Frank P. Dow Co., 322 I.C.C. 103, 124 (1964). On the other hand, these nationwide carriers dominate the industry. See 1964 TaAspont STatistics (PART 8).

30. In 1948, the ICC denied that the public interest required that surface foriarder entry be restricted in order to prevent dilution of traffic and wastage, or that entry could be restricted simply because the new service would compete with existing forwarders. Lifschultz Fast Freight Extension, 265 I.C.C. 431, 439-44 (1948), aff'd sub nom. Acme Fast Freight, Inc. v. United States, 338 U.S. 855 (1949) (per curiam). In a later decision, the ICC described its pre-1958 policy as holding that

where shippers desired and would use the newly competitive forwarder service pro. posed, authorization of that service would be consistent with the public interest and the national transportation policy unless it was shown that institution of the new service would result in serious impaiment of existing forwarder service.

Frank P. Dow Co., 322 I.C.C. 103, 111-12 (1964).

31. 49 U.S.C. $\$ 1010$ (d) (1964). The provision was left in effect only insolar as it applied to rail-controlled applicants, the evident purpose of this exception being to preserve the ability of railroads to set up forwarders to handle their increasing unprofitable LCL trafic. See H.R. REP. No. 880, 85th Cong., lst Sess. 3 (1957).

32. Frank P. Doty Co., 322 I.C.C. 103, 113 (1964). See also Norman G. Jensen, Inc, 318 I.C.C. 719, 724 (1963) ("A finding of inadequacy . . . is therefore penultimate to a finding of need for a new similar service....? 
unless one can show, at the threshold, that existing service is inadequate. ${ }^{33}$

Forwarder rates, like those of other common carriers under ICC jurisdiction, may be suspended for investigation upon filing or may be challenged at any time. The forwarder is forbidden to establish unjust or unreasonable rates or to create undue preference or discriminations among persons or places. ${ }^{34}$ The ICC is empowered to set maximum and minimum or actual forwarder rates. The pattern of forwarder rate regulation parallels motor and rail carrier rate regulation, except that there is less argument about the level of costs in forwarder rate cases, for about 70 per cent of forwarder costs, on average, are for current outlays to direct carriers for transportation services. ${ }^{35}$ Surface forwarder rates are commonly on a par with the rates of whichever direct carrier is the closest competitor for the traffic involved..$^{30}$ The competitive advantages of the surface forwarders today are largely service advantages -greater speed of service, single carrier liability, ease of tracing shipments, and minimization of the need for shipper contact with carriers. ${ }^{37}$

The law restricts ICC freight forwarders to the use of direct common carriers for the transportation services they provide, excepting "the performance within terminal areas of transfer, collection or delivery services." 38 Within terminal areas, the forwarder may provide his own collection and delivery service, or may hire an unregulated trucker. ${ }^{30}$

33. The words of the amendment are permissive and not mandatory. The fact that the ICC has interpreted them so strictly against the policy of free entry into surface forward. ing reveals the Commission's attitude toward competition.

34. 49 U.S.C. \$\$ 1005-06 (1964).

35. 1964 Transport Statistics (Part 8).

36. Statement of Giles Morrow, General Counsel, Freight Forwarders Institute, Hearings on the Transportation Act of 1963 (H.R. 4700 and H.R. 4701) Before the House Comm. on Interstate and Foreign Commerce, 88th Cong., lst Sess. 530-32 (1963).

37. Id. The surface forwarders grossed $\$ 487$ million in 1964, handling almost 20 million shipments weighing a total of about 4.4 million tons. Net after-tax profits were $\$ 5.1$ million, but if the loss for Republic Carloading is excluded, the net industry profits were about $\$ 6.9$ million. 1964 Transport Statistics (PART 8). (Republic Carloading was purchased by Yale Express in early 1964; the combined firms went bankrupt in early 1965 duc largely to poor management of the acquiring firm. See Whalen, The Big Skid at Yale Express, Fon. TUNE, November 1965, at 144.) Of total 1964 revenues, about \$163 million went straight to the railroads for line-haul transportation expenditures, and an additional \$86 million went to motor carriers for line-haul service. The proportion of line-haul transportation costs flowing to motor carriers has been increasing steadily since 1957. Similarly, costs for assem. bly and distributing service, as a proportion of the total, have been crecping upwarl. This is probably due as much to increased distance of assembly and distribution movements as to relatively greater costs of such movements. The most noteworthy change in forwarder service in recent years is the growing forwarder reliance upon container and TOFC operations. In 1965, the forwarders originated about 11 per cent of the total number of trailers moving in TOFC service. Interstate Commerce Commission, Transport Economics, March 1966, at 3.

38. 49 U.S.C. § 1018 (1964).

39. The unregulated trucker will most likely be a trucker operating under the terms of 
The law also restricts the ties of surface forwarders with other carriers. The provisions, however, are asymmetric, in that a direct carrier (or person controlling a direct carrier) may acquire control of a forwarder, but a forwarder (or person controlling a forwarder) may not acquire control of a direct carrier. ${ }^{40}$ The apparent rationale of this system was to permit railroads to create forwarder subsidiaries for their small-shipment traffic, without allowing forwarders the supposed competitive advantage of owning a captive direct carrier."1

\section{The Air Freight Forwarder}

Air forwarders, although operating no aircraft, are classified as indirect air carriers under section 101(3) of the Federal Aviation Act, which defines as an air carrier anyone "who undertakes, whether directly or indirectly . . . , to engage in air transportation," and then further provides that the $\mathrm{CAB}$ may exempt air carriers "not directly engnged in the operation of aircraft in air transportation" from such provisions of the Act as it finds to be in the public interest. ${ }^{42}$ In lengthy proceedings between 1948 and 1958, the Board formulated rules applicable to domestic and international air forwarding, the most important of which permits air forwarders to operate without a certificate of public convenience and necessity. ${ }^{43}$

In contrast to ICC-regulated forwarding, air forwarding is open to anyone who can satisfy standards of capability and fitness, and complies with certain insurance, reporting, and tariff-filing requirements. ${ }^{4 i}$ In

section 203(b)(8) of the Interstate Commerce Act, 49 U.S.C. $\S 303(b)(8)$ (1964), which permits the ICC to exempt from economic regulation local cartage carricrs within the commercial area of any city, although they may: be carrying commodities moving in interstate com. merce.

40. 49 U.S.C. $\$ \S 1010(c), 1011(a)$, (g) (1964).

41. Although the provisions permitting direct carricr control of surface forwarders were probably originally intended to permit rail ownership of forwarders, recent years have seen the end of rail control of freight forwarders and the growth of motor carrier purchase of forwarder. The ICC estimated in 1963 that perhaps as much as 50 per cent of total forwarders tonnage was moved by firms owned by or under common control with motor carriers. 77 ICC ANN. REP. 118 (1963). Some of the common control situations may involve only small motor carriers, but two of the biggest forwarders, National Carloading and Republic Carloading, are owned by P.I.E. and Yale Express, respectivcly.

42. 49 U.S.C. \$ 1301(3) (1964). See Railway Express Agency, 2 C.A.B. 531 (1941), in which the $\mathrm{CAB}$ decided that it would be inappropriate to grant indirect air carriers certificates of public convenience and necessity under the terms of section 401 of the Civil Acronautics Act, now section 401 of the Federal Aviation Act, 49 U.S.C. $\S 1371$ (1964).

43. Air Freight Forwarder Case, 9 C.A.B. 473 (1948); Air Freight Formarder Cace (International), 11 C.A.B. 182 (1949); Airfreight Forwarder Investigation, 21 C.A.B. 530 (1955); International Airfreight Forwarder Investigation, 27 C.A.B. 658 (1958). The rules formulated by the CAB in these cases are at 14 C.F.R. $\$ \S 296$ (domestic air freight forwarding), 297 (international air freight forwarding) (1966).

44. See 14 C.F.R. $\$ \S 296-97$ (1966). The air forwarder is considerably more important 
1955, the Board was urged by several forwarders and direct air carriers to require public hearings on forwarder applications to determine their fitness and the existence of a public need for additional service. ${ }^{40}$ It replied that its staff was competent to determine fitness, and that a public need test was only appropriate to the entry and certification of direct air carriers. ${ }^{48}$ "[T] $]$ he question whether a particular forwarder's services would fill a public need [was] left to the judgment of the shipping public itself." 47 Air forwarding authorizations are granted separately for domestic (interstate) and international (all other) service, but otherwise impose no restrictions on points served or commodities carried. An air forwarder may hold both domestic and international authority. Rate regulation, like entry control, is left to competitive forces. The Board rejected a 1958 plea by the airlines that it subject air forwarders to minimum rate orders, ${ }^{48}$ and the issue has been moot since minimum freight rates for direct air carriers were removed in $1961 . .^{40}$

The issue of outside financing and control of air forwarders has arisen only in connection with surface carrier entry into air forwarding. Section 408(b) of the Federal Aviation Act provides that ownership, operation, or control of air carriers by other air carriers or surface carriers must be approved by the Board as being in the public interest. ${ }^{60}$ The

in air cargo transportation than is the surface forwarder in surface freight transportation. In 1964, the air forwarders originated 22.2 per cent of domestic air cargo tonnage, while the surface forwarders originated less than 1 per cent of rail tonnage. Information Exhibit No. 11, p. I, Docket 16857; 1964 Transport Statistics (PART 8); 79 ICC ANN. REP. 155, Table 10 (1965). The air forwarders, however, move much less tonnage than the surface forwardcrs, handling only 210,000 tons in domestic and international service together in 1964 . Information Exhibit No. 2, p. 2, Docket 16857. The air forwarding industry has one large firmEmery Air Freight-which, in 1964, originated about 30 per cent of domestic tonnage and earned about two-thirds of the total profits in domestic air forwarding. Direct Exhibit No. 7 , pp. 1-4, Docket 16857. Most other large forwarders were in the black for their domestic services, but few other international air forwarders did more than break even, Id.

45. Airfreight Forwarder Investigation, 21 C.A.B. 536, $548-49$ (1955).

46. Id. at 549-50.

47. Id. at 550. To provide some control over the number of outstanding forwarder authorizations, the $\mathrm{CAB}$ will revoke them for failure to engage in forwarding over any two. year period. 14 C.F.R. $\$ \S 296.49,297.44$ (1966). From 1962 to 1965, the GAB revoled 22 dormant authorizations. Information Exhibit No. 4, Docket 16857.

48. Airfreight Rate Case, Minimum Rates for Airfreight Forwarders, 26 C.A.B. 399 (1958). The $\mathrm{CAB}$ concluded that the public interest would be best served if the forwarders were permitted to set their prices to the public without regard to the rates of the direct carriers. It reasoned that the imposition of minimum rates would raise small package prices, and held that the appropriate regulatory policy was the encouragement of pricing based on lowest possible costs: the air forwarders were held to spccialize in the non line-haul function of air transport and thereby able to achieve economies not open to the dircct air carrier. Id. at $341-42$.

49. Minimum Rates Applicable to Airfreight, 34 C.A.B. 263 (1961). The one cxisting exception to this rule is the Puerto Rican market, where minimum rates have been in effect since early 1966. Docket No. 11278, New York-San Juan Cargo Rates Investigation, 2 Av. L. REP. If 21,646 (CAB, June 21, 1966); Id. at I 21,618 (CAB, March 28, 1966).

50. 49 U.S.C. \& $1378($ b) (1964). 
$\mathrm{CAB}$ interprets the Act to apply a similar rule even when surface carriers desire to enter air transportation in their own names, rather than through subsidiaries, a relationship not technically within the prohibitions of section 408.51 It has denied surface carrier applications for air forwarding authority when it believed that the surface carrier was not wholeheartedly interested in the development of air transportation services. ${ }^{52}$

Air forwarders, like direct air carriers, may operate motor vehicles to provide pickup and delivery service for cargo they handle. The Interstate Commerce Act exempts this service from motor carrier economic regulation when it is "incidental to transportation by aircraft." current ICG and CAB procedures, this is interpreted to permit exempt service within about 25 miles of airports. ${ }^{64}$ Beyond this area, air forwarders must have surface forwarding authority from the ICC, or must turn the shipments over to ICC-regulated common carriers. ${ }^{.5}$

\section{The Maritime Non-Vessel-Operating Common Carrier}

The non-vessel-operating common carrier, the "NVO," has received comparatively little attention. 68 This obscurity reflects the structure of

51. Air Freight Forwarder Case, 9 C.A.B. 473, 502 (1948).

52. Id. at 510 . The $\mathrm{CAB}$ granted air forwarding rights in this proceeding to about ten small motor carriers, noting that their operations would be useful in the consolidation and distribution of air shipments. Id. at 508. It likewise granted the requests of independent surface forwarders for air forwarding rights. Id. But it denied authority to rail-owned or controlled air-forwarder applicants, anguing that their extensive facilities, together with rail financial backing, would be detrimental to the development of healthy competition in the industry. Id. at 509-12, aff'd sub nom. National Air Freight Forwarding Corp. v. CAB, 197 F.2d 384 (D.C. Cir. 1952). The CAB reversed itself seven years after its original decision on the grounds that the appearance of successful independent air formarders lessened the danger to competition posed by rail financial backing. Airfreight Forwarder Investigation, 21 C.A.B. 536, 545 (1955). The CAB has consistently refused to grant Railsiay Express Agency a general airforwarding authorization, on the grounds that REA's contractual relations with the airlines for the provision of Air Express Service (a special cargo service using REA vehicles for expedited pickup and delivery service and having first loading priority after passengers' baggage and the U.S. mails) would be inconsistent with REA provision of air cargo services as an ordinary air freight forwander. REA therefore remains as a unique class of indirect air carrier. See Air Freight Forwarder Case, 9 C.A.B. 473, 489 (1948); Railway Express Agency, 2 C.A.B. 531 (1941). The Board is presently faced with the decision of whether or not to grant the application of several very lange motor carriers for domestic and international forwarding authorizations. Docket 16857, Mrotor CarrierAir Freight Investigation (1966). Its staff is on record as opposed to the granting of authority, based on the great size of the trucking firm in relation to existing air forwarders and on the fact that their "prime economic incentives are in a competing mode of trans. portation." N.Y. Times, Jan. 23, 1967, at 86, col. 5 .

53. 49 U.S.C. \& $303(\mathrm{~b})(7 \mathrm{a})$ (1964).

54. See 14 G.F.R. \$222 (1966); Snow, Air Freight Forwarding: A Legal \& Economic Analysis, 32 J. OF AIR L. \& CoMm. 485 (1966); Note, Regulation of Air Freight Pichup and Delivery, 76 YAIE L.J. 405 (1966).

55. See 49 C.F.R. § 404.1 (1967 Supp.) (use of regulated motor common carrier service by an air freight forwarder); 49 C.F.R. $\S 210.40$ (1967 Supp.) ('motor transportation of property incidental to transportation by aircraft").

56. Maritime forwarder regulation is made confusing by a problem in nomenclature. 
ocean carrier cargo tariffs, which, for the most part, make consolidation unprofitable. The unit of carriage-the ship-is too large for the forwarder to consolidate full loads, and the tariffs do not provide "weight breaks" comparable to those which make air freight forwarding profitable. ${ }^{57}$ Most present NVO's are surface carriers which have expanded into NVO operations in order to provide their inland customers with through service to overseas points. It is expected that the increasing use of containerized shipments in international transportation will create a greater demand for NVO services in the maritime trade..$^{68}$

The earliest case involving an NVO held that it was a common carrier by water because it had long-term cargo space contracts with the vessel operator. ${ }^{50}$ Maritime regulation of freight forwarding was not

The Federal Maritime Commission describes the maritime indirect carrier as a "non-vesseloperating common carrier" or "NVO." The "independent ocean freight forwarder" in the maritime industry is not an indirect carrier, as described in this paper, but rather is an agent of the shipper who procures transportation service for and in the name of the ship. per. This paper is limited to an analysis of the indirect common carrier, and generic refer. ences to "freight forwarders" or "maritime forwarders" must therefore be understood to refer only to the non-vessel-operating common carrier.

The difference in names stems from the fact that in the maritime trade, the old-style "forwarder," serving as a shipper's agent, supra note 7, never disappeared. As a result, when the indirect, maritime common carrier first appeared, a different name had to be found. The FMC's predecessors simply adopted the functional name-"Non-vesscl-opcrating common carrier:" See Investigation of Practices of Ocean Freight Forwarders, 6 F.M.B. 327 (1961); Agreements and Practices Pertaining to Brokerage, and Related Matters, 3 U.S.M.C. 170 (1949); Port of New York Freight Forwarder Investigation, 3 U.S.M.C. 157 (1919); House Comat. on Merchant Marine and Fishertes, Investigation into the Activities of Foreign Freight Forwarders and Brokers, H.R. Rep. No. 2939, 84th Cong,, 2d Sess. (1956). In 1961, the Shipping Act of 1916 was amended to provide a statutory definition of the independent ocean freight forwarder, and to provide for the licensing and rules of com. pensation of independent ocean freight forwarders. 75 Stat. 522 (1961), 46 U.S.C. \$\$ 801, 841 (b) (1964).

57. This fact helps explain the continued existence of the shippers' agent (the "independent ocean freight forwarder") in the maritime industry. See discussion in note 50 supra. Because there has been little or no room for the forwarder to operate by consolidat. ing shipments, the shipper has had to deal directly with the underlying carrier. But becatuse many shippers are at inland points where steamship operators have no offices, it has becn economically desirable to have agents at seaports to deal in the name of shippers with the underlying carriers. If the steamship operators structured their rates to encourage the growth of the indirect carrier in the maritime trade, one would expect to sce considerable decimation of the "independent ocean freight forwarders" (the shippers" agents).

58. See pp. 1365-66 supra. Many motor carriers of household goods already provide such service, using special household goods containers to provide through scrvices requiring no handling of the furnishings in transit. See Common Carriers by Water, supra note 27. One of the country's largest motor carriers, Denver-Chicago, has been advertising a similar general commodity service from the Midwest to Europe in conjunction with a Holland-based motor carrier affiliate.

59. Alaskan Rates, 2 U.S.M.C. 558, 582 (1941). It was apparently the contract featurc of the Railway Express Agency transportation which led the Maritime Commission to term REA a common carrier, for another firm which consolidated shipments to Alaska and moved them under its own bill of lading, assuming full liability for loss and damage but not making special contracts with the underlying carrier, was held not to be a common carrier by water. Id. It is noteworthy that this decision was prior to both the CAB decision holding REA to be an indirect air carrier, note 42 supra, and the 1942 Act placing surface forwarders under ICC regulation, 56 Stat. 384 (1942), 49 U.S.C. $\S \S 1001.22$ (1964). 
brought into line with ICG and CAB regulation until 1952 when the Federal Maritime Board held that the status of a common carrier depends upon the nature of the service offered to the public, and not upon the existence of any particular form of contractual relations between the NVO and the underlying carrier."

Since the legislation governing the NVO does not distinguish between the NVO and the direct carrier, the regulatory powers of the Federal Maritime Commission, successor to the FMB, must apply equally to both. ${ }^{61}$ The NVO is required to file tariffs with the FMC and to submit for review all agreements fixing rates or otherwise providing for restrictions of competition among persons subject to FMC regulations. ${ }^{62}$ In the domestic offshore trade, the FMC has rate regulation powers over common carriers similar to those of the ICC, but in foreign trade, the FMC may only prescribe the form of tariffs, prohibit rebating, and disapprove rates which it finds to be so unreasonably high or low as to be detrimental to the commerce of the United States. ${ }^{.3}$ All common carriers and other persons subject to FMC authority must, however, avoid undue preferences or discriminations between persons, places, or types of traffic. ${ }^{04}$ Because the FMC cannot restrict entry into direct maritime transportation, it cannot restrict entry into indirect maritime transportation.

\section{Present Law: The Need for Change}

If the freight forwarder is to play an expanded role in the coordination and provision of intermodal transportation, this legal framework must be rationalized. Not only different regulations but also different philosophies of regulation govern the ICC surface forwarder and the $\mathrm{CAB}$ air forwarder. The ICC treats surface forwarders as it does the direct carriers, which is to say that the ICC tends to act something like the governing body of a cartel, allocating business so that the survival

60. Bernhard Ulmann Co. v. Porto Rican Express Co., 3 U.S.A.C. 771 (FMB, 1952). The Board was obviously influenced in reaching its decision by its observation of the post1941 practice of the ICC and the CAB.

61. See maritime statutes cited note 1 supra. The NVO is mentioned in the FMIC regulations only in the course of distinguishing the NVO from the "independent ocean freight forwarder." 46 C.F.R. \$ 510.21(d) (1966):

The term "non-vessel operating common carrier by water" means a person who holds himself out ... to provide transportation for hire by water . . . assumes responsibility or has liability imposed by law for safe transportation of shipments; and arranges in his own name with underlying water carriers for the performance of such transportation ...."

62. Common Carriers by Water-Status of Non-Vessel Carricrs, 6 F.M.B. 245 (1961).

63. 46 U.S.C. $\$ \S 816-17$ (1964).

64. 46 U.S.C. $\$ 815$ First (1964). 
of each mode of transportation is assured. The $C A B$ views the air forwarder largely as a tool for developing air freight, rather than as a potential instrument of intermodal transport coordination. ${ }^{\circ 5}$ So far, the maritime agencies have not considered the NVO's important enough to formulate a clear regulatory policy.

The development of intermodal freight forwarding depends upon the answers to certain basic questions. Should the forwarder be limited to small shipments which require consolidation and break-bulk services? How much rate regulation is necessary? Are entry controls required? Can forwarders receive rates from carriers other than those received by ordinary shippers in similar circumstances? Should forwarders be allowed to affiliate with direct carriers?

The following sections of this study examine the existing patterns of forwarder regulation in more detail to determine the changes that would facilitate intermodal forwarding. The form of certain recommendations stems from the realization that it is normally easier to reinterpret statutes or revise administrative regulations than to pass new laws. Ideally, an agency with no ties to any particular mode of transportation should be responsible for freight forwarding. In practice, it will probably be necessary to settle for representatives of the existing transportation regulatory commissions sitting as an ad hoc agency for purposes of forwarder regulation.

\section{Entry into Freight Forwarding}

The ICG's policy of restricting entry into freight forwarding makes sense only as a means of protecting established forwarders from the threat of additional competition. As discussed above, the ICC has taken the 1957 amendment to section 410 of the Interstate Commerce $\mathrm{Act}^{\text {to }}$ as a license to make new entrants show that service is inadequate before they can receive operating permits. Both this amendment and the ICC's interpretation appear to be founded upon the false belief that free entry will involve "improvident and wasteful duplication of transportation services and facilities." ${ }^{67}$ The ICC's own figures indicate that

65. Cf. Airfreight Forwarder Investigation, 21 C.A.B. 536, 546 (1955) ("our policy . . . will stimulate the growth of airfreight and its utility to the public"\%, and Air Freight Forwarder Case, 9 C.A.B. 473, 509-12 (1948) (discussing the reasons for denial of air forwarding authority to rail-controlled applicants).

66. 49 U.S.C. \& 1010(d) (1964). See notes 31-33 supra, and pp. 1367-68.

67. This phrase appears in both the Senate and House Reports on the measure, S. REp. No. 542, 85th Cong., 1st Sess. 4 (1957); H.R. REP. No. 880, 85th Cong., 1st Sess. 4 (1957). It was parroted by the Commission in West Coast Freight Co., 309 I.C.C. 123, 127 (1959), in which a permit was denied, although no mention of the 1957 amendment appears any-
where in the decision. 
forwarders need only a minuscule investment in capital equipment, which can easily be adapted to other uses if the forwarder is forced out of business. In 1964, the railroads' total operating income was over $\$ 9.5$ billion; their net investment in transportation property was $\$ 24.9$ billion. ${ }^{68}$ In that same year, the gross income of ICC-regulated forwarders was $\$ 487$ million, while their net investment in transportation property was only $\$ 6$ million. ${ }^{63}$ Thus the forwarders' capital-output ratio is less than $1 / 200$ that of the railroads. ${ }^{70}$ If all the forwarders went out of business tomorrow and their transportation investment were shot into space, the net loss to society would be less than $1 / 60$ of the annual rail passenger deficit. ${ }^{.1}$

This figure may even overstate the amount of capital committed to freight forwarding, because much of the equipment is readily transferable to other uses. Most of the forwarder's investment is in pickup and delivery vehicles and trailers or containers-both of which have a ready resale market-and in consolidation and break-bulk facilities-which also have substantial alternative use value.72 Easy exit and entry are

68. 79 ICG ANN. REP. 152, 153 (1965).

69. 1964 Transport Statistics (Part 8).

70. Any argument that competitive forwarder services involve great danger of wasteful, duplicative investment is lacking in candor. As two dissenters in the 1964 Dow case pointed out, the number of forwarders holding ICC permits was actually decreasing from 1952 onwards, during the period in which the ICC was pressing for amendment of section 410 (d). In 1952, 96 forwarders held permits; in 1957 there were 89, and by 1964 there vere only 82, 10 of which were inactive. Frank P. Dow Co., 322 I.C.C. 103, 124 (1964); 1964 Transport Statistics (PART 8). The 1957 amendment is thus perhaps best viewed as a fight between the haves and the have-nots within the industry, rather than a fight between es. tablished firms and new entrants.

71. The deficit in 1964 was $\$ 410.2$ million. 79 ICC ANw. REP. 80 (1965). Altcmatively; the surface freight forwarders sometimes argue that unrestricted entry rill bring more competitors in any one market than there is traffic to support them, so that no one for. warder will receive enough traffic to make consolidation profitable. See, c.g., Statement of Giles Mforrow, General Counsel, Freight Forwarders Institute, Hearings on Freight Forwarder Legislation (S. 3365, etc.) Before a Subcomm. of the Senale Comm. on Interstale and Foreign Commerce, 84th Cong., 2d Sess. $41-43$ (1956). But there is no evidence that this has ever occurred; the ICC's 1957 legislative recommendation noted only that "the case with which permits may be obtained . . . could result in overcrowding . . . Ictter from the ICC to the Senate Committee on Interstate and Foreign Commerce, id. at 4 (emphasis added). And the statute makes provision for this possibility by permitting forwarders who at any time are unable to consolidate sufficient traffic to use carlozd or truckload rates to "joint load" and together obtain the carload rate advantage. 49 U.S.C. $\S 1004($ d) (1964).

72. The forwarder's greatest capital requirement may be working apital. Normally; the forwarder pays the underlying carrier before he collects from the shipper. This apital requirement may be a hindrance to entry, but it certainly cannot be classified as an clement of wasteful investment likely to result from over-strenuous competition. Forriarder tangible capital requirements are lessened by the ability of forwarders to lease much of their plant and equipment: forwarders engaged in Plan IV TOFC service may lease the flatcars necessary on a short term basis. Flatcars and trailers, of course, are readily uable in any other form of TOFC service or by another forwarder if the lesse formarder should go out of business. 
fundamental characteristics of a market that is best regulated by competition..$^{73}$

Of course, regulation of entry into freight forwarding is not based exclusively on the danger of wasteful investment. Forwarders are expected to offer common carrier standards of liability and care to shippers-standards that shoestring entrants may be unable to meet. A shipper should not have to check the Dun and Bradstreet rating of every forwarder who competes for his business.

The $\mathrm{CAB}$ standards provide a reasonable compromise between totally uncontrolled entry and the competition-restricting practices of the ICC. Since air forwarder service was authorized in 1948, the Board has continually rejected suggestions that air forwarders be required to show a public need for their services. ${ }^{74}$ The $C A B$ has wisely avoided attempts to formulate any fixed criteria of fitness: in practice, it determines fitness on an ad hoc basis from the forwarder's application, which provides general information about the transportation background of applicant's managing personnel, its financial resources, its chief stockholders and its relations with other transportation-connected enterprises. ${ }^{75}$ The direct financial interests of the public and air forwarder customers are protected by mandatory forwarder insurance requirements. These mild regulations have been sufficient to keep the industry stable, contrary to the predictions of the advocates of restrictions on free entry.76

73. It does not appear that there are any substantial cconomies of scale in surface forwarding. In 1964, Frank P. Dow Co. earned $6.0 \%$ on gross revenues of $\$ 650,000$; Midland Forwarding earned $4.2 \%$ on $\$ 4.4$ million; National Carloading earned $0.9 \%$ on $\$ 35.4$ mil. lion; and Universal Carloading earned $1.1 \%$ on $\$ 73.4$ million. 1964 TRANSPORT STATISTICS (PART 8) 8-9. This is not to imply that there are necessarily cliseconomies of scalc: Western Carloading, the most profitable forwarder in terms of dollar earnings, earned $6.1 \%$ on gross revenues of $\$ 43.0$ million. Id.

As long ago as 1948, the ICC stated that it ought to be able to deny forwarder permit applications when existing service was considered "adequate." See Lifschultz Fast Frcight, 265 I.C.C. 431, 438-39 (1948), aff'd sub nom. Acme Fast Freight, Inc. v. United States, 398 U.S. 855 (1949) (per curiam). But the prior existence of "adequate service" should be ir. relevant unless entry into an "adequately-served" market is shown to correspond incvitably with such undesirable results as impairment of service to shippers or uneconomic invest. ment by carriers. This the ICG has never done. The use of the "adequate service" rubrlc removes all danger of competitive pressure from new entrants into surface forwarding. It would not be feasible for the ICC to formulate standards for "adequate" service which would approximate the standards which would be imposed on the industry if therc werc free entry.

74. See pp. 1369-70 supra; Airfreight Forwarder Investigation, 21 C.A.B. 536, 549 (1955).

75. See 14 C.F.R. $\S \S 296.42,297.32$ (1966) for the information required of air forwarder applicants. Most applications which do not involve questions of surface carrier participation in air forwarding appear to be granted. Applicants whose initial applications arc rejected by $\mathrm{CAB}$ staff are entitled to submit new information and to request a public hearing. 14 C.F.R. $\$ \S 296.43,297.34$ (1966).

76. E.g., the pessimistic dissenting opinion of Member Jones in the 1948 casc, 9 C.A.B. 437, 523-24. 
These standards are an appropriate pattern for uniform treatment of forwarder entry by the three regulatory agencies. Section 410 of the Interstate Commerce Act need not prevent the ICC from adopting them. The Commission only has to determine as a matter of policy that it is not in the public interest, as that phrase is used in section 410 (c), to deny permits on the grounds of adequate existing service. $i 7$ Only if the ICC refuses to change its present position will legislation be required.

Forwarders ought to be spared the ordeal of appearing before two or three separate agencies to obtain permission for intermodal service. One approach, if the ICG can be persuaded to change its entry policy, is to have the staff of each agency jointly evaluate applications and simultaneously submit identical recommendations for agency approval. If the Commission refuses to accept a change in its policy on forwarder entry, the most satisfactory solution would be legislation, along the lines of the unsuccessful Transportation Act of 1963, establishing a joint board with an equal number of members from each of the three transport agencies. ${ }^{78}$ This board would have power to decide whether or not the potential forwarder has the minimal technical competence and financial backing necessary to safeguard the interests of the shipping public and the direct carriers. Existing forwarders, operating in only one mode of transportation, would have grandfather rights to that service, but ought, like new entrants, to satisfy the minimum fitness requirements for any expansions of their service to different modes. It is implausible that any of the expansion-minded firms currently operating would not be able to satisfy such tests; and the form of test proposed, involving as it does no public hearing, should be no great burden upon them.

\section{Quantitative Limitations on Forwarder Service}

Even under a policy of free entry, there may be dispute over the physical limits on freight forwarder service. Specifically, should the forwarder be allowed to handle shipments on which he performs no consolidation service? Presently the ICG, the $C A B$ and the FMC all have different rules governing this question, but intermodal forwarders will require a single standard. Although the forwarder is routinely described as a carrier which makes its living consolidating small shipments into

77. 49 U.S.C. $\$ 1010$ (c) (1964).

78. S. 1062, 88th Cong., 1st Sess. (1963), section 4(b). The text may be found in Hearings on $S .1061$ and $S$. 1062 Before the Subcomm. on Surface Transportation of the Senote Comm. on Commerce, 88th Cong., lst Sess. 7-9 (1963). 
truckloads or carloads, there is no reason why it must be limited to such service. $^{79}$ If the shipper is prepared to pay a premium for single carrier responsibility and service, especially in international air and maritime transportation, he should be permitted to do so. ${ }^{80}$

The Interstate Commerce Act and the regulations of the CAB both define the indirect carrier as one which "in the ordinary and usual course of its undertaking" assembles and consolidates, and breaks bulk and distributes, shipments. ${ }^{81}$ The requirement of assembly and consolidation places a potential limitation upon the size of shipments which the forwarder may handle, for the forwarder who receives straight carloads or truckloads from shippers performs no consolidation services.

In the case of the $C A B$, this limitation is only potential. The phrase "ordinary and usual" is not in the Federal Aviation Act, but in the regulations. Moreover, the $\mathrm{CAB}$ has made no effort to restrict the size or weight of air forwarder shipments. The present regulations permit both the international and the domestic air forwarder to charter aircraft, which would seem to authorize the forwarder to handle full planeload shipments. ${ }^{82}$

The ICG, however, interprets "ordinary and usual" less freely, although the precedents are confusing. In 1961, it seemed to say that some activity which can be labelled as consolidation and break-bulk services is a prerequisite for the performance of all surface forwarder service. ${ }^{83}$ And regardless of shipment size and weight, if the surface forwarder is primarily engaged in handling truckload and carload lots, without assembly and consolidation, the ICC presently will hold him to be operating beyond the limits of his authority. ${ }^{84}$ But in the 1966

79. Discussion about the issues in forwarder rate regulation raised by large volume forwarder shipments will be postponed to the following section.

80. As pointed out above, p. 1364 supra, the large volume shipper is likely to have less need for the services of a forwarder. He has the size to justify maintaining his own internal traffic management staff, who will be familiar with the alternative transportation possibilities available from each mode of transportation. But even the large volume shipper may have occasional unusual shipments with which his staff has no experience.

81. ICC: 49 U.S.C. § 1002(5) (1964); CAB: 14 C.F.R. §§ 296.2, 297.2 (1966).

82. 14 C.F.R. $\$ \$ 296.22,297.22$ (1966).

The ability of forwarders to charter aircraft does not mean that the air forwarder is going to be able to obtain rates which the shipper of air freight cannot obtain: the shipper is free to charter as well, so that if he can make use of the full capacity of the plane, lic is in the same position as the air forwarder. The discussion at pp. 1379.80 infra, applics, mutatis mutandis, to air transportation.

83. Boots or Shoes from Bel Camp, Md., 313 I.C.C. 137, 138 (1961) (forwarder "volume rate" for light-loading shoes held to involve the forwarder in direct shipper-to-consignce truckload movements, which were "not a freight-forwarder service").

84. Motor Rail Co., 296 I.C.C. 205, $214-15$ (1955) (“. . . Motor Rail's preponderant operations .... are the transportation of full truckload shipments of specific commodities.... 
Brinke case, with no mention of its 1961 position, the Commission ruled that "[i]n order to retain the status of freight forwarder, it is not necessary for applicant to assemble and consolidate, and break bulk and distribute as to every shipment which he handles." 85 Moreover, in an earlier case, the Commission had stretched the concept of assembly and distribution to the breaking point by accepting forwarder provision of TOFC service: the forwarder was found to be providing assembly and consolidation service within the Act when he places two trailers, each from a separate shipper and filled only with the goods of that shipper, on a single flatcar. ${ }^{86}$

The two sets of cases may be reconciled by noting that in the 1961 decision, the Commission was striking down filings which would inevitably produce carload or truckload movements, and therefore would never involve consolidations. Thus rates which produce trailerload movements for TOFC service, where there is pro forma consolidation of two trailers on one flatcar, would be outside the proscription of the 1961 ICG decision. ${ }^{87}$

Nevertheless, given its precedents, the ICC would have to act affirmatively to establish the right of freight forwarders under its jurisdiction to handle shipments of any size. ${ }^{88}$ But if the ICC is willing, legislative change would be unnecessary, for the phrase "ordinary and usual" is flexible enough to encompass occasional shipments for which no consolidation or break-bulk services are performed. An interpretation of

85. Brinke Freight Forwarder Application, 326 I.C.C. 322, 325 (1960). Brinke proposed to operate TOFC forwarder service out of Miami, Florida. His proposed tariff included alternative higher rates to cover the eventuality that at any given time he might not hare an even number of trailers to "consolidate" on TOFC flatcirs for a given destination. The flatcars take two trailers; the railroads charge a higher per-trailer raie if a car carries only one trailer. Brinke's opponents claimed that any movements of only one trailer on a fist car would not involve consolidation and hence not be within the Interstate Commerce Act. This argument was rejected by the Commission in the phrase quoted in the text. See also Dinion Coil Co. v. International Forwarding Co., 304 I.C.C. 1, 3 (1958) (in a shipper reparation suit for overcharges on a carload shipment moving in forward service, held, forwarder entitled to apply his rates to carload shipments if the shipper chose forwarder service, since consolidation and break-bulk are not required on every shipment).

86. Forwarder Volume Commodity Rates, 310 I.C.C. 199, 203 (1960), af'd sub nom. Eastern Express, Inc. v. United States, 198 F. Supp. 256 (S.D. Ind. 1961), affd per curiam 369 U.S. 37 (1962).

87. The motor carriers have attacked forwarder provision of large shipment service on the grounds that forwarders are somehow inherently limited to relatively small shipments. The Commission has rejected this argument, holding, in effect, that the statutory concolidation and break-bulk rules are the only effective limits on the size of formarder shipments. Forwarder Volume Commodity Rates, 310 I.C.C. 199, 201, 203 (1960).

88. It would be necessary, as well, to clarify previous holdings which imply that a forwarder must provide both consolidation and breali-bulk service on any given shipment. The "ordinary and usual" provision in the Act should be interpreted to provide that although both services are normally provided in freight forwarder shipments, they need not invariably be provided. See Class Rates, 303 I.C.C. 293, 298 (1958); Kagarise Freight Forwarder Application, 260 I.C.C. 745, 747 (1946). 
the Interstate Commerce Act which permits shipper-loaded truckloads to move in forwarder TOFG service should also permit the infrequent movement of larger shipments. Large surface forwarder shipments will be relatively infrequent because of the rule that direct carriers must treat the forwarder as a shipper. ${ }^{80}$ When the forwarder is treated as any other shipper, the direct carrier cannot publish rates for the exclusive benefit of the forwarder by name. The rate may be structured in a manner which makes it more likely to be used by forwarders than by other shippers, but any shipper who can meet the specifications of the rate may ship property under that rate. At present, most surface forwarder shipments in rail service between consolidation and break-bulk points move under "all-commodity" or "freight, all kinds" rates. ${ }^{.0}$ If the forwarder may utilize a rail all-commodity rate to ship carloads of a single commodity at a lower rate than the rate nominally applicable to that specific commodity, an ordinary rail shipper should likewise be able to take advantage of that rate. When the shipper of carload lots can obtain the same rate that the forwarder pays, the forwarder will find that he can engage in carload operations only where he can provide premium service. Since the forwarder and the shipper must pay the same basic rate to the railroad, premium service will involve premium charges. Ordinarily, the large shipper's market power and internal transportation expertise will make the forwarder's service superfluous. But if the ship. per is willing to pay a premium, perhaps in order to obtain through single-carrier service or to avoid the cost of maintaining transportation expertise within his own firm, it should be possible for him to do so. With one exception, elimination of which is recommended in connection with forwarder rate regulation, ${ }^{91}$ the argument applies equally well to forwarder use of motor carrier services. If the forwarder begins to handle straight truckload lots, he must provide some form of premium service in order to compete with the direct motor carriers.

No problems of statutory or regulatory restrictions on shipment size arise in maritime forwarding. FMC regulations simply define the NVO as an indirect carrier by water, selling water transportation as a common carrier and arranging in its own name with underlying water carriers for the actual transportation. ${ }^{92}$ There is no requirement of the

89. See p. 1363 supra.

90. Cf. All-Commodity Rates, 293 I.C.C. 327 (1954); All Freight to Pacific Coast, 248 I.C.C. 73 (1941). It is clear that forwarders are not the exclusive beneficiaries of such rates: large volume, general merchandise shippers are also substantial users of them, 248 I.C.C. at 82-83.

91. See pp. 1381-85 infra.

92. 46 C.F.R. \& 510.21(d) (1966). 
performance of consolidation and break-bulk services, and therefore no need to change the maritime regulations to conform to the change recommended for ICC-regulated forwarders. Nor in fact is there any substantial likelihood of controversy over NVO consolidation and break-bulk service: the single unit of transportation-the ocean cargo vessel-is so large that break-bulk and consolidation are likely to be an inevitable part of the NVO's service.

\section{Freight Forwarder Rate Regulation}

In the Lehigh Valley case, the Supreme Court established the principle that regulated direct carriers must charge forwarders their published tariff rates for transportation services. ${ }^{93}$ Were it not for a partial exception to this principle for forwarder shipments moving by motor carrier, there would be no good reason for independently regulating freight forwarder rates, except to eliminate special discriminations for or against particular shippers. The maximum rates which the forwarder could charge without providing better service than the underlying carrier would be fixed by the rates available to shippers from the underlying carriers themselves. Correspondingly, the minimum rates could be no less on a per-pound basis than the rates the forwarder would have to pay the underlying carrier, for otherwise the forwarder would operate at an out-of-pocket loss. Should any rate distortions occur within this limited range, they will not be long-lasting: entry into forwarding is so easy that no single competitor is likely to acquire significant market power.

The forwarders, however, have never been happy with the Lehigh Valley doctrine: they argue that the direct carriers achieve certain economies in the movement of forwarder traffic not applicable to the traffic of other shippers, and that these economies should be reflected in lower rates for forwarder shipments. Ideally, the forwarders seek to be recognized as carriers able to make joint rates with the underlying carriers, with only the total, and not the division, subject to the approval of a regulatory agency. ${ }^{04}$ While they have had no success with this argument in air and rail transportation, the forwarders have obtained partial relief from the Lehigh Valley principle in their transactions with motor carriers; and therefore the regulated rates of the motor carriers cannot serve as a competitive check on forwarder rates.

93. See notes $11-13$ supra and p. 1363 .

94. See, e.g., Hearings on S. 2113 Before the Senate Comm. on Interstate and Foreign Commerce, 81st Cong., lst Sess. (1949). 
Section 409 of the Interstate Commerce Act permits motor common carriers to give special "contract" rates to surface forwarders. For linehaul movements of up to 450 miles, these rates may be less than the tariff rates of the motor carriers available to shippers in general..$^{\circ 5}$

The section 409 rate privilege, coupled with the recommendation above, that forwarders be allowed to handle shipments of any size and weight, may give the forwarder a substantial competitive advantage over the regulated motor carrier, operating independently of the forwarder. Low section 409 rates from a motor carrier would permit a forwarder to charge a shipper truckload rates less than the going rates of regulated motor common carriers for identical service.

Economic incentive to the motor carrier to offer such bargain rates to the forwarders could exist in two situations. First, by offering section 409 rates to a cooperative freight forwarder, a motor carrier can effectively lower its rates without going through the formalities of tariff amendments. Section 409 rates, unlike ordinary motor carrier tariff rates, are not open to investigation and suspension, so other carriers cannot object to them. ${ }^{26}$ This exemption for section 409 rates could easily lend itself to selective "skimming" of profitable traffic. Section 409 rates would serve as the functional equivalent of discriminatory rebates.

The second incentive could come from the use of "trip-leasing," where a holder of motor common carrier operating rights owns no vehicles but obtains equipment on an as-needed basis, leasing it from single vehicle owner-operators for individual trips. Because the owneroperator may be seeking a back-haul, he will often be willing to accept a lease rate barely above his out-of-pocket costs. The motor carrier can then turn around and use section 409 to grant low contract rates to a

95. 49 U.S.C. \& 1009 (1964). The section provided, after the 1950 Amendment, 64 Stat $1114(1950)$, that forwarders could establish contract rates with motor carriers, provided that these rates did not unduly prejudice or prefer any of the participants thereto or any other forwarder, and provided that no contract for line-haul service of 450 miles or morc could provide for rates less than those which the motor carriers are required to establish under the rate-making provisions of Part II of the Act. Section 409(b) of the Act and 49 C.F.R. \& 400.1 (1964) require all section 409 rate agreements to be filed with the Commls.
sion, "on paper of good quality, size $81 / 2 " \mathrm{x} 11$ "."

Forwarder assembly and distribution services may also be provided by motor carriers on section 409 rates. But this is a separate problem, more closely concerned with the type of carrier a forwarder may use to provide this service, and is best considered in connection with the general problems of assembly and distribution services. See pp. 1891-95 infra.

96. Section 409 requires only that all 409 contracts be filed with the ICC. See note 95 supra. The ICC has indicated that it has not been able to do much with 409 rate contracts except file them. Hearings on Freight Forwarder Acquisitions (S. 684) Before the Surface Transportation Subcomm. of the Senate Comm. on Commerce, 88th Cong., Ist Sess. 12 (1963) [hereinafter cited as 1963 Freight Forwarder Acquisition Hearings]. 
freight forwarder. He thereby evades the regulation of his own rates and is able to give the forwarder lower rates than he can obtain from a motor carrier which operates its own fleet of vehicles. ${ }^{07}$ This, too, may lend itself to the skimming of profitable traffic and selective ratecutting. In both cases, the combination of the motor carrier and freight forwarder rates would be open to no regulatory control at all unless the rates of the forwarder were themselves under direct supervision of the regulatory agency.

Legislative prohibition of section 409 rates for all freight forwarder line-haul shipments between consolidation and break-bulk points will eliminate this difficulty. The forwarders, however, would surely claim that this would bankrupt them and bar them from handling small shipments as well as from handling truckload movements. But it should be possible to develop a scheme which would continue to make lower rates available to forwarders for their movements of consolidated small shipments, while curtailing forwarder access to special rates for truckload movements.

First, all forwarder shipments, small or large, should be able to move at lower rates via any direct carrier if lower direct carrier costs are in fact incurred in handling forwarder shipments. Although quantity discounts based on transportation requirements contracts are illegal, ${ }^{98}$ regulatory commissions are still expected to accept rates which are

97. An example of just this kind of forwarder involvement in truckload service through the medium of section 409 rates is found in Motor Rail Co., 296 I.C.C. 205 (1955).

98. The railroads cannot grant quantity discounts to shippers on the condition that the shipper tender a minimum proportion of his shipments to the railroad. Contract Rates, 313 I.C.C. 247, aff'd sub nom. New York Central R. Co. v. United States, I94 F. Supp. 947 (1961), affd per curiam 368 U.S. 349 (1962). The same rule applies to motor common carriers, Liquified Petroleum Gas, 16 Fed. Car. Cases I 35,859 (1965). In air transportation, freight tariffs include several weight breaks at which the cost per pound drops, a practice which is probably justified by cost savings in handling larger shipments. But the CAB has also permitted the use of "blocked-space" agreements, whereby a carrier buys space at a fiat fee, whether or not he uses it for shipping anything, at a rate substantially lower than regular rates. American Airlines v. CAB, 359 F.2d 624 (D.C. Cir.) (Affg CAB Economic Order 21160), cert. denied, 385 U.S. 843 (1966). This is arguably different from a minimum percentage requirement contract, for here the rate is open to a shipper with no restrictions upon the disposition of his total air transport requirements. Rates of this kind serve a different purpose than the requirements contracts invalidated in Contract Rates, supra. Air cargo services are largely scheduled services primarily involving small shipments. "Blocked-space" rates assure the carrier of revenue for space which, if not used, would be moved anyway by the carrier: there is no way to move one-half of a DC-B. The rates in Contract Rates were for multiples, rather than fractions, of the unit capacity of the carrier. By these rates, the carrier was not obtaining payment for transportation which it would necessarily perform under any circumstances. Only in maritime transportation are "requirements-contract" rates permissible under the dual rate system approved by Congress in 1961, 75 Stat. 762 (1961), 46 U.S.C. \$ 813a (1964), amending the Shipping Act of 1916. But because maritime tariffs include few or no weight breaks (see p. 1372 supro), this will not permit the NVO to obtain rate advantages for large shipments which the shipper himself could not obtain. 
based on cost differences. ${ }^{90}$ In the simplest case, a shipper who tenders ten carloads at once may obtain a lower per-car rate than a shipper who tenders only one car at a time. Moreover, rates reflecting the cost savings in doing business with forwarders would hardly deviate from present law. ${ }^{100}$ Section 408 of the Interstate Commerce Act presently permits motor carriers to publish special rates for surface forwarder assembly and distribution services when those services can be provided at a lower cost than ordinary short-haul small shipment services, ${ }^{101}$

Secondly, the agencies should permit special rates for all largevolume, mixed-commodity shipments, whether the carrier is dealing with a forwarder who consolidates small shipments or a large-scale shipper of mixed commodities. Rates of this kind have existed for some time in rail service.102 They are theoretically open to all shippers but typically include geographic and commodity-mix restrictions which make them suitable for use only by freight forwarders and high-volume general merchandise shippers. ${ }^{103}$ Motor carriers instituting rates with similar restrictions should be able to avoid any loss of revenue resulting from shipper desire to move truckload single-commodity shipments at

99. Minimum volume rates, on the other hand, appear to be acceptable to the ICC in two situations. First, low rates for very high minima have been approved, typically to re* tain traffic which would otherwise be lost to non-regulated transportation. Typically thesc rates are for power-station coal, to meet the threat of mine-mouth or oil-fircd gencratingt plants, as in Coal from Ky., 308 I.C.C. 99 (1959). Second, volume rates are permitted when
lower costs are clearly shown, Grain in Multiple Car Shipments, 325 I.C.C. 752 (1965). Thic reasoning of these cases should apply to all modes of transportation.

100. It would be necessary, in order to stay within the limits of the Lehigh Valley prin. ciple, to permit any shippers whose traffic meets the standards set for the forwarder rates to take advantage of these rates. Direct carriers cannot set rates for forwarders qua for. warders. The probability that only a few shippers will be able to meet the conditions should not in itself render the rate unreasonably discriminatory so long as the rate is costrelated. Prior to surface forwarder regulation, the Supreme Court did affirm an ICC ruling that forwarders could not receive lower rates from motor carricrs than other shippers, United States v. Chicago Heights Trucking Co., 310 U.S. 344 (1940). But the rates dis* allowed were for assembly and distribution services of less-than-truckload lots, and not for line-haul service. Moreover, in that decision, the Court gave deference to the ICG's finding that the rates challenged were in fact unequal rates covering substantially identical services.

101. 49 U.S.C. $\$ 1008$ (1964). These rates may also be used by large shippers with multiple plants at either the shipping or receiving end. The most common non-forwarder user would be a firm like Sears, Roebuck shipping in carload lots from a distribution center to a major market area, with the shipment broken down for distribution to cach retail storc at a central point in the market area, and moving to the individual stores on scction 408 assembly and distribution rates.

102. See p. 1380 supra.

103. All-commodity rates for forwarder TOFC service normally apply only when no commodity is more than 60 per cent of the shipment. Forwarder Volume Commodity Rates, 310 I.C.C. $199,200(1960)$. If the 60 per cent limit is exceeded, the charge to the forwarder for the full trailerload is normally based on the dominant commodity. Since this rate will normally be greater than the all-commodity rate, and will be approximately the same rate available to the true owner of the property, the railroad will have lost little or no reventie because the shipment has moved in forwarder service instead of being turned over directly to the railroad by the true owner. 
all-commodity rates whenever the all-commodity rate is lower than the single-commodity rate.

This combination of a prohibition against rate concessions to forwarder on single-commodity shipments which are not based on cost savings, and a permissive policy toward motor vehicle "all-commodity" or "freight, all kinds" rates, would prevent forwarders from obtaining an undue advantage over motor common carriers for single-commodity truckload movements. At the same time, this policy should not interfere significantly with the movement in forwarder service of consolidated small shipments. That is, the forwarders should be able to survive without the benefit of section 409 rates between consolidation and break-bulk points. If the forwarder handles carload or truckload shipments, it will be on the basis of service advantages it provides the shipper (such as intermodal coordination in export service), and not because of rate concessions that only a forwarder is able to obtain from the underlying carrier.

Turning to the maritime field, in domestic offshore traffic the FMC has regulatory powers over carrier rates paralleling those of the ICC and the GAB. ${ }^{104}$ In foreign trade, however, the FMC has only the power to disapprove rates which do not meet the statutory standards. ${ }^{105}$ Although the direct maritime carrier and the NVO are subject to the same standards, the FMG appears to have made no effort to oversee the rates charged by the NVO's beyond requiring that they comply with the act by filing their tariffs with the FMC. ${ }^{100}$

Presumably, the Lehigh Valley doctrine applies in the maritime industry. FMC regulations governing the operations of the shipper's agent (commonly called the "independent ocean freight forwarder" but unrelated to the NVO) in the maritime industry indicate that an NVO is in violation of the law if it accepts rebates or special privileges from the direct ocean carriers, unless these privileges are available to all shippers and are not classified as rebates by the FMC. ${ }^{107}$ If the steamship operators persist in granting differentially lower rates to the NVO's, the FMG would appear to have the power to order their removal whenever they constitute an unreasonable preference or prejudice.

It is probably safe to assume that the FMC and the CAB will con-

104. 46 U.S.C. \& 817 (a) (1964).

105. 46 U.S.C. $\$ \$ 815$ First, 816,817 (b) (1964).

106. Common Carriers by Water-Status of Non-Vessel Carricrs, 6 F.M.B. 245 (1961).

107. Cf. 30 Fed. Reg. 1849 (1965). 
tinue their policy of leaving freight forwarder rates substantially un. regulated, and there is no need for special legislation to achieve this purpose. Part IV of the Interstate Commerce Act, regulating surface freight forwarders, does not lend itself to such simple solution. Section 406 may be construed as requiring the Commission to fix forwarder rates wherever it believes existing rates are unreasonable. ${ }^{108}$ Furthermore, the Commission is noticeably less sympathetic to unregulated transportation than are the other regulatory agencies. These two facts suggest that not only may it be necessary to permit the Commission to exempt forwarders from maximum and minimum rate regulation: it may also initially be necessary to require the ICC to grant the exemption when it is permitted by statute.

Forwarder exemption from general rate regulation is preferable to statutory denial of this power. It would be over-optimistic to expect that shippers will never complain of forwarder overcharging or discrimination, or that direct carriers will never accuse forwarders of misbilling shipments to gain more favorable rates. ${ }^{100}$ There are two possible forums for resolving such disputes: the courts and the adjudicative administrative agencies. At present jurisdiction over such questions as preferential or discriminatory rates, unlawful charges to shippers and carriers, and rebating is given to the regulatory agencies. It would create undesirable complications to diverge from this pattern for the relatively small segment of transportation encompassed by freight forwarding.

On the other hand, it would be equally undesirable to submit intermodal forwarders to the separate jurisdiction of the three agencies on questions of this sort. Disputes between shipper and forwarder, or direct carrier and forwarder, would be a natural subject for the joint board proposed above to oversee entry into freight forwarding. 110 The board should not, however, be given specific rate-fixing powers. Instend, remedies for discriminatory or unjust forwarder practices should be limited to reparations or cease and desist orders. To the extent that forwarder practices found to be discriminatory or prejudicial involve forwarder rates and are not already corrected or capable of being corrected in the immediate future by competitive pressures, the for-

108. 49 U.S.C. $\$ 1006(b)$ (1964) (". . . it shall determine and prescribe the lawful rate ....".

109. This has been a perennial problem in air forwarding: the more marginal air forwarders apparently have not always been able to resist the temptation to submit to the direct air carriers a 450 pound shipment at a billing weight closer to 400 pounds.

110. See p. 1377 supra. 
warder ought to be permitted to eliminate the wrong as he sees fiteither by bringing the discriminatory rates into line with his general rate structure, or by bringing other rates into line with the heretofore discriminatory rates.

\section{Ownership and Control of Forwarders}

An additional area of concern is the affiliations between direct and indirect carriers. At present each agency has its own standard. The $\mathrm{CAB}$ is consistently opposed to orwnership or control relations between air forwarders and air carriers. It has not exempted the air forwardex from the statutory provisions requiring $\mathrm{CAB}$ approval of interlocking relationships between air carriers and others engaged in aeronautics, and of agreements affecting competition in air transportation. ${ }^{111}$ It forbids acquisition of air forwarders by other common carriers when, in its judgment, such acquisitions would be detrimental to the development of air cargo service. ${ }^{112}$

The maritime NVO is subject to the same rules as the direct maritime carrier. Since no control or entry restrictions presently apply to transportation under FMC jurisdiction, there is no statutory provision for FMC supervision over relations between NVO's and direct carriers. The only potential control stems from the requirement that all agreements restricting competition between persons subject to the Act (socalled "section 15 agreements") be filed with the FMC, which has the power to disapprove those it finds to be unduly restrictive and not in the public interest. ${ }^{113}$

The surface forwarders under ICC regulation are subjected to more detailed statutory control of their relationships with direct carriers. Sections 410 and 411 of the Interstate Commerce Act permit a direct carrier subject to the Act or person controlling or controlled by a direct carrier, to acquire control of a surface fowarder. But an ICC direct carrier may not itself receive a surface forwarder permit, and a surface forwarder, or person controlling or controlled by a surface forwarder,

111. 49 U.S.C. $\S \S 1378-79,1382$ (1964). See Air Freight Forwarder Case, 9 C.A.B. 473, $500(1948)$

112. The Board has statutory power to deny such acquisitions if it finds that they will restrain competition or will not satisfy the requirement that they promote the public interest. Section 408(b) of the Federal Aviation Act, 49 U.S.C. $\S 1378(b)$ (1964). The CAB interprets the Act to apply a similar rule even when surface carriers desire 10 cnter air forwarding in their own names, rather than through subsidiaries or acquisitions, a rela. tionship not technically within the prohibitions of section 408. Air Freight Forvarding Case, 9 C.A.B. 473, 502 (1948). See note 52 supra, discussing $\mathrm{CAB}$ restrictions on surface carrier entrance into air forwarding.

113. 46 U.S.C. § 814 (1964). 
may not acquire control of an ICC-regulated direct carrier. ${ }^{114}$ Although the surface forwarders have sought permission to acquire surface direct carriers, or, in the alternative, to block surface carrier acquisition of forwarders, their efforts have been fruitless. ${ }^{115}$ They do have grounds for dissatisfaction, because there are no persuasive economic arguments for the ICC's asymmetrical policy on acquisitions.110

Although the ICC has indicated a preference for placing control relationships between direct carriers and surface forwarders under section five of the Interstate Commerce Act, ${ }^{117}$ it would be more sensible to abandon the regulation of these relationships for all modes of transportation. There are two objections to unrestricted control relationships between direct and indirect carriers. First, it is feared that the direct carriers may, via their subsidiaries, monopolize the market for indirect transportation services. By receiving special treatment from the parent company, the subsidiary freight forwarder would be able to give better service at equal rates, or equal service at lower rates, and thus obtain a freight forwarding monopoly. But a direct carrier operating in a competitive market will find that discriminatory service or prices designed to freeze out independent forwarders will simply cause these forwarders to shift to other direct carriers, and the would-be monopolist will, instead, be faced with a declining market share. The direct carrier with a monopoly should be indifferent to the degree of competition among forwarders. It can establish a single rate schedule for all forwarders so that, allowing for the return on investment necessary to keep the forwarders in the market, the forwarders "produce" at the level of output which maximizes the direct carrier's profits. It can do no better by setting up its own forwarding subsidiary and discriminating against its independent competitors, for, in the first situation, the direct carrier has already obtained all of the monopoly profits to be made in that market. Only if the direct carrier is subject to effective maximum rate regulation would it be desirable to monopolize forwarder traffic via a subsidiary. Regulated maximum rates will prohibit

114. 49 U.S.C. $\$ \S 1010(\mathrm{c}), 1011(\mathrm{a})$, (g) (1964). See note 41 supra and accompanying text. 115. See, e.g., 1963 Freight Forwarder Acquisition Hearing; Hearings on Freight For. warder Legislation (S. 3365, etc.) Before a Subcomm. of the Senate Comm. on Interstatc and Foreign Commerce, 84th Cong., 2d Sess. (1956).

116. Statement of L. Walrath, Chairman, ICC, 1963 Frcight Forwarder Acquisition Hearings 4-5. On the problem which can arise from these provisions, see Calore Express Co., 87 M.C.C. 379 (1961).

117. The ICC has proposed either placement of all surface carrier-surface forwarder relationships under section five of the Interstate Commerce Act, or prohibition of all ownership or control relations between direct and indirect surface carriers, including severance of existing ties. It prefers the former alternative. 1963 Freight Forwarder Acquisition Hear. ings 5, 10-11. 
the direct carrier from exploiting its monopoly position when it sells transportation services to shippers, including forwarders. But if the direct carrier can exclude independent forwarders by providing them with inadequate service, its own forwarder subsidiary (whose rates, by our hypothesis, are unregulated) will be able to obtain a monopoly of the market for forwarder services. ${ }^{118}$

Monopoly achieved by discrimination, however, violates existing law. The Lehigh Valley doctrine bars any form of preferential rates or rebates from direct carriers to freight forwarders, subsidiaries or independents. ${ }^{119}$ It should apply equally strongly to service discrimination, for there is no economic distinction between favoritism in rates and favoritism in service. ${ }^{120}$ The regulatory agencies therefore have ample authority to prevent the regulated monopolist from achieving a second monopoly in the forwarder market.

The second objection is that the captive forwarders will rig their tariffs so that their shipments travel via the affliated direct carrier for as long as possible. This will involve non-optimal resource allocation if total shipment costs would have been minimized by a different combination of transport modes; in effect, the carrier will be providing inferior service. But given free entry into freight forwarding, the direct carrier controlling a forwarder can sustain inferior service only by taking a loss on the subsidiary's freight forwarding operations or by giving its subsidiary rate or service advantages not available to independent forwarders. The rate and service advantages are, as has already been shown, illegal under existing law: the direct carrier must

118. The volume of monopoly profits available in forwarding is likely to be relatively small. The demand for forwarder services depends both on the existence of alternative means of transportation and the demand for the product being transported. Many smallscale shippers may have a ready alternative to the freight forwarder in the less-than-truckload services of the motor carriers. Others, if dependent on forwarder service, may not be competitive in their product markets if their costs rise vis-d-vis more adiantageously located producers, and will simply stop shipping.

119. Lehigh Valley R.R. v. United States, 243 U.S. 444 (1917).

120. There seem to be no cases involving simple service discrimination; an assertion of its illegality is but a reasonable extension of the existing law of carricr discriminatory practices. Lehigh Valley was decided on the basis of sections 2 and 6 of the Interstate Commerce Act, 243 U.S. at 446. Section 2 prohibits collection of differential compensation for the performance of "like . . . service in the transportation of a like kind of traffic under substantially similar circumstances and conditions ..."49 U.S.C. \& 2 (1961). Identical compensation for different levels of service should fall within this proscription. Similarly. the Elkins Act (which provides special penalties, including injunctive relief, for its violation) forbids carriers to give "any rebate, concession, or discrimination . . . whereby" [transportation is provided below published tariff rates or] . . any other advantage is given or discrimination is practiced ...." 49 U.S.C. $\$ 41(1)$ (1964). The Supreme Court has commented, "In fact, favoritism which destroys equality between shippers, however brought about, is not tolerated." Union Pacific R.R. v. United Statcs, 313 US. 450, 402 (1941) (applying the Ellkins Act). 
provide independent forwarders with the same rates and services it makes available to its subsidiary. If the controlling direct carrier is content with sub-normal profits from the subsidiary's indirect carrier operations, we may not understand it, but there are no apparent reasons for subjecting this generosity to legal sanctions.

A rational economic basis for discrimination in favor of a forwarder subsidiary does exist, of course, when the common control results in efficiencies not obtainable by the independent forwarder. The history of forwarder relations with direct carriers before forwarders were brought under regulation in 1942 does not suggest that appreciable economies exist. But if there are such efficiencies, there is no good reason to prohibit them, at least until Congress establishes a coherent policy against corporate size.

A similar argument should apply to forwarder ownership or control of direct carriers. The Lehigh Valley doctrine would still bar the "captive" direct carrier from granting lower rates to the parent forwarder, unless it at the same time granted lower rates to all other forwarders and shippers similarly situated. And in a market in which there is easy entry, selective price-cutting to drive other forwarders out of the market, financed by profits earned elsewhere by the direct carrier, would not be a profit-maximizing course of action for the controlling forwarder; it would in effect be sacrificing normal profits in order to maintain a monopoly.

Theory therefore suggests that there should be no restrictions on financial or corporate relationships between direct and indirect carriers so long as direct carrier rate regulation and the Lehigh Valley doctrine continue to apply. Two alternatives are available to those who fear the unforeseen deviant case. The anti-trust laws could be invoked. But since indirect carrier-direct carrier relationships resemble vertical integration between wholesaler (or producer) and retailer, and since anti-trust law has not been conspicuously successful in formulating a coherent theory of vertical integration, this would be an unsatisfactory means of public control. The second possibility is to rely upon the tripartite board proposed above in connection with entry and discriminatory forwarder rate practice. The legal definition of forwarder discriminatory practices could be formulated to include prohibition of singlehanded or joint attempts at monopolization of indirect carrier services. These prohibitions would apply both to forwarders and to direct carriers in control relationships with forwarders, although provision ought to be made for the situation in which common control of direct 
and indirect carrier services creates efficiencies which cannot be matched by the independent forwarder.

\section{Freight Forwarder Provision of Assembly and Distribution Services}

It will be particularly difficult to establish a uniform pattern of regulation for the forwarders' assembly and distribution services. Although freight forwarders are normally forbidden to move shipments by any means other than regulated common carriers, surface and air forwarders are allowed to use unregulated motor transport for assembly and distribution services covering relatively short distances. ${ }^{121}$ Because the air and surface forwarder exemptions are not identical, each type of forwarder-maritime, surface and air-is subject to a different set of rules governing assembly and distribution services. Their contradictory requirements would severely burden an intermodal freight forwarder. To use the existing exemptions, the intermodal forwarder would be required to separate shipments moving in assembly and distribution service both on the basis of the line-haul carrier which moved them from consolidation to break-bulk point and according to the distance involved in the assembly or distribution operation.

Among the three classes of forwarders, the clearest regulations apply to maritime NVO's: they can provide no surface assembly and distribution services at all, exempt or otherwise. The Interstate Commerce Act exemption from motor carrier regulation of water carrier terminal area pickup and delivery services applies only to water carriers under ICC regulation. ${ }^{122}$ But most NVO's have a separate status as surface carriers (direct or indirect), which will define their rights to provide unregulated motor vehicle assembly and distribution services. ${ }^{123}$

Section 202(c) of the Interstate Commerce Act permits surface forwarders to use their own vehicles or those of others for "the performance within terminal areas of transfer, collection, or delivery services . . ." 124 Common carrier authority is not required for these services: forwarder terminal area service is regulated as part and parcel of the forwarder service itself. ${ }^{125}$ All surface forwarder service beyond

121. 49 U.S.C. $\S 1018$ (1964); 14 C.F.R. $\$ \S 296.97$ (1966).

122. 49 US.C. \$ 302(c) (1964). Trans-Caribbean Motor Transport, Inc, 60 M.C.C. 593, 597 (1956).

123. E.g., the carriers who were parties to Common Carricrs by Water-Status of NonVessel Carriers, 6 F.M.B. 245 (1961).

124. 49 U.S.C. $\$ 302$ (c) (1964).

125. 49 U.S.C. $\$ \S 302(\mathrm{c}), 1010(\mathrm{~h}), 1018$ (1964). Forwarders may, in the alternative, hire unregulated carriers to perform such service. See note 39 supra. In such a situation, the service is to be regulated as though it were performed by the forwarder himself. 
the terminal area (which rarely extends more than five miles beyond the corporate limits of the central municipality) must utilize the services of a common carrier authorized by the ICG to operate between the consolidation or break-bulk points and the consignor or consignee of the shipment. ${ }^{126}$

Prior to motor carrier regulation, the forwarders negotiated for special rate reductions for all assembly and distribution services, but thereafter, non-tariff forwarder assembly and distribution rates were held illegal under the Lehigh Valley principle. ${ }^{127}$ However, section 409 of the Interstate Commerce Act, discussed above in reference to forwarder line-haul movements, ${ }^{128}$ also permits forwarders to obtain favorable contract rates for assembly and distribution services. ${ }^{120}$ At present, almost all surface forwarder assembly and distribution services beyond the exempt terminal area move on section 409 rates.

Indirect air carrier provision of assembly and distribution services for air cargo is subject to a third set of rules. Section 203(b)(7a) of the Interstate Commerce Act, ${ }^{130}$ exempting the transportation of property by motor vehicle from economic regulation by the ICC when "incidental to transportation by aircraft," has been construed by the ICC to permit air carriers (direct and indirect) to operate exempt motor vehicle transportation within a distance of twenty-five miles from the airports served by the carrier. ${ }^{131}$ The ICG has further construed section 203(b)(7a) to mean that an air forwarder cannot act as an indirect carrier beyond the limits of the exemption provided by 203(b)(7a)

126. 49 U.S.C. \$ 1018 (1964). The ICC has defined the terminal zones of freight forwarders and motor carriers as equal to the "commercial zone" in section 203(b)(8) of the Act, 49 U.S.C. $\$ 303(\mathrm{~b})(8)$ (1964), within which exempt local cartage carriers are permitted to operate. Commercial Zones and Terminal Areas, 54 M.C.C. 21, 64-66 (1952); 49 C.F.1R. $\$ \S 170.45,170.48(1964)$. The formula for determining the limits of a commercial zone for cities of 5,000 to 100,000 or more inhabitants is at 49 C.F.R. $\$ 170.16$ (1964). Section 170 also contains exceptions to the general formula for specific cities.

127. Acme Fast Freight, Inc., 17 M.C.C. 549 (1939), aff'd, 30 F. Supp. 968 (S.D.N.Y. 19.4), aff'd per curiam 309 U.S. 638 (1940).

128. See pp. 1381-82 supra. Section 409 did not take its present form until 1950, 64 Stat. 1114 (1950). An outline of the events between 1942 and 1949 may be found in Hearings on S. 2113 Before the Senate Committee on Interstate and Foreign Commerce, 8lst Cong., lst Sess. 4-5 (1949).

129. 49 U.S.C. \$ 1009 (1964). See note 95 supra. The forwarders and motor carriers have arranged for assembly and distribution service rates under section 409 rather than under section 408, 49 U.S.C. $\$ 1008$ (1964); see p. 1384 supra. The shortcoming of section 408 apparently is the requirement that the rates be tariff rates available to all comers; the motor carriers feel that assembly and distribution services need to be tailored more closely to the individual forwarder than section 408 permits in order to avoid committing themselves to the provision of unprofitable service.

130. 49 U.S.C. § 303(b)(7a) (1964).

131. Motor Transportation of Property Incidental to Transportation by Aircraft, 95 M.C.C. 71 (1964), 49 C.F.R. \& 210.45 (1967 Supp.). 
without obtaining surface forwarder authority from the ICG. ${ }^{132}$ Lacking this authority, the air forwarder is limited to charging his applicable rate to (or from) the air terminal. The published motor carrier tariff rate between the air terminal and the ultimate origin or destination points must apply to the surface portion of the trip, and the air forwarder must make it clear to shippers that the motor carrier is performing a connecting service, with the air forwarder assuming no common carrier liability for that portion of the journey. ${ }^{133}$

The intermodal freight forwarder will, at one and the same time, be an air, maritime and surface forwarder, and this will smooth out some of the contradictions in the three regulatory schemes. The intermodal forwarder will not be affected by the limitations on assembly and distribution services provided by air and maritime forwarders. The forwarder will be able to act in his alter ego as surface forwarder when he handles air or maritime shipments, and accordingly will be governed by the rules applicable to surface freight forwarder assembly and distribution service.

This, however, is only half the solution. Section 203(b)(7a) specifcally exempts service "incidental" to air transportation from all ICC economic regulation, ${ }^{134}$ whereas section 202 (c) merely states that surface forwarder collection and delivery service within terminal areas will be regulated as part of forwarder service, instead of being separately regulated as motor carrier service under Part II of the Interstate Commerce Act. ${ }^{135}$ The two sections therefore remain incompatible with regard to the forwarder assembly and distribution services which may be performed only by regulated motor common carriers: the air forwarder may utilize a carrier not subject to ICC economic regulation for journeys of up to twenty-five miles, while the surface forwarder may utilize an unregulated carrier only within its terminal area as defined by the ICG, a distance normally much less than twenty-five miles. ${ }^{130}$

Because section 202(c) regulates both motor carrier and surface freight forwarder terminal area services, and 203(b)(7a) regulates both direct and indirect air carrier pickup and delivery services, any change

132. Panther Cartage Co., 88 M.C.C. 37 (1961).

133. Motor Transportation of Property Incidental to Transportation by Aircraft, 95 M.C.C. 71, 89-90 (1964). See 49 C.F.R. \$ 404.1 (1967 Supp.), where these rules are set forth in more detail. The power of the ICC to establish rules of this form was affirmed in Air Dispatch, Inc. v. United States, 237 F. Supp. 450 (E.D. Pa. 1964), aff'd per curiam 381 U.S. 412 (1965).

134. 49 U.S.C. $\S 303(b)(7 a)$ (1964).

135. 49 U.S.C. \& 902 (c) (1964).

136. See pp. 1391-93. 
in either provision will have some effect upon the existing competitive balance between one or both pairs of carriers. The solution which would least disturb the existing balance would be the definition of "terminal area" service and service "incidental to transportation by aircraft" as service performed within identical areas. ${ }^{137}$ This regulationfree area ought to be somewhat larger than the present commercial zones as defined by the ICC, ${ }^{138}$ to which surface forwarder terminal areas are presently equated. Whereas the present commercial zone rarely extends much more than five miles from the limits of the central city of the zone, the "terminal area" proposed for redefinition here should be defined to include the major economic tributaries of the central city. Mechanical rules, like the current five and twenty-five mile limits, may relieve the regulatory commissions from creative responsibility, but they bear little relationship to a city's economic geography. ${ }^{130}$

This recommendation would cut down substantially upon the service which air carriers, direct and indirect, may provide free of all ICG regulation, but it would be counter-balanced by two factors. First, the traffic moving by indirect air carrier would have access to section 409 contract rates, for the indirect air carrier could become at will an indirect surface carrier. This would provide the indirect carrier with rates lower than the published motor carrier tariff rates for surface movements beyond the newly-defined terminal areas. ${ }^{140}$ Second, the

137. This definition avoids the question of the size of the terminal areas within which rail companies, express companies, and water carriers subject to the ICC's authority may perform transfer, collection, and delivery services under section 202(c). Because the ICC has not attempted to fix limits to the terminal areas of these carriers, they are currently free to fix their own terminal areas in the tariffs they publish, subject to ICC disapproval.

138. See note 126 supra.

139. The introduction of this larger terminal area is likely to raise questions about the extent of the exemption granted to local cartage carriers, which, under Section 203(b)(8) of the Interstate Commerce Act, may be exempted from all economic regulation within the commercial zone of a city. 49 U.S.C. $\S 303(\mathrm{~b})(8)(1964)$. This paper does not seck to deal with the problem of the local cartage carrier. If good arguments can be made that it would be unwise to extend the area of regulatory freedom granted these carriers, the ICC need only end its present policy, not demanded by the statute, of equating the scction 202(c) "terminal area" and the section 203(b)(8) "commercial zone."

140. Reliance upon section 409 contract rates for assembly and distribution service beyond the regulation-free indirect carrier terminal area may create one difficulty. The argument for freedom of indirect carriers from rate regulation depended upon their use of direct carrier rates which were themselves subject to regulation. If very long distance assembly and distribution services appear, the line-haul element of the total cost to the forwarder could decrease in importance, and hence would be a lesser constraint on the rates which the forwarder gives to the public. See p. 1381 supra. It is conccivable that competition among motor carriers through the medium of unrestricted section 409 rates might result in substantial instability among indirect carriers and motor carriers. Compare the problems involved in the use of section 409 rates for the provision of line-haul services for forwarders, pp. 1381-83 supra. Section 409 does empower the ICG to insure that section 409 contracts are not prejudicial to cither of the participants or to other freight forwarders, but the ICC has rarely exercised this power. Testimony of L. Walrath, ICC Chairman, 1963 Freight Forwarder Acquisition Hearings 12. 
access of the indirect air carrier to section 409 contract rates would be paralleled by the right of the direct air carrier (and only the direct air carrier) to establish joint rates with surface direct carriers for through service. ${ }^{141} A$ joint rate between a local and a long distance carrier is normally less than the sum of the two independent rates published for the line-haul and the local portions of the journey. ${ }^{142}$ In surface forwarding, section 409 contracts are believed to result in the same split between the line-haul motor carrier and the forwarder as would result from the division of a joint rate between local and long-haul motor carrier. ${ }^{143}$ Assuming similar results would arise from agreements between direct air carriers and motor carriers, air shipments would be subject to substantially identical rates whether the air portion of the movement were handled in the first instance by a direct or an indirect air carrier.

Moreover, if it appeared that regular common carriers are unable to fill the specialized needs of air transportation service beyond the limits of the newly-defined terminal area, the ICC could expand its existing practice of certifying motor common carriers limited solely to the transportation of property with a prior or subsequent movement by air. ${ }^{144}$ Motor common carriers limited to the transportation of property with a prior or subsequent movement by indirect carrier would be able to provide the specialized assembly and distribution service which a general-commodities motor common carrier might be unwilling to attempt.

This proposal would leave the relative competitive position of sur-

Should section 409 rates for assembly and distribution services beyond the terminal area limits become seriously disruptive, it might be necessary to fall back upon section 403 of the Interstate Commerce Act, 49 U.S.C. \$ 1008 (1964). See note 128 and p. 1384 supra. The alternative to section 409 contract rates are open tariff rates published especially for assembly and distribution services, but subject to ICC cxamination (like any other tariff rate) to determine whether they are justified by the costs of performing the service.

If assembly and distribution services beyond terminal area limits must be provided on tariff rates, the ability of indirect carriers to arrange speedy, flexible pickup and deliver; service probably will be impaired. Because tariff rates, even under section 408, must be filed well in advance of their effective date and are subject to investigation and suspension, changes in rates may lag substantially behind changes in traffic. Therefore the goal of enhancing intermodal coordination through the encouragement of the indirect carrier would appear to call for the retention of section 409 contract rates for assembly and distribution services, at least until it can be demonstrated that this retention is undesirable.

141. Federal Aviation Act \& 1003(b), 49 U.S.C. \& 1483(b) (1964).

142. That is, the separate motor carrier rate from New Haven to New: York may be $\$ 3.50$ per hundred pounds, and the air rate to Los Angeles from New York $\$ 30.05$ per hundred. A joint rate might be $\$ 31.00$, New Haven to Los Angeles, with $\$ 28.00$ going to the air carrier and $\$ 3.00$ to the motor carrier. [These figures are purely hypothetical.]

143. 1963 Freight Forwarder Acquisition Hearings 23. (Testimony of Giles Morrow, General Counsel, Freight Forwarders Institute.)

144. See White Air Freight Service, Inc., 95 Xr.C.C. 616 (1961). 
face forwarders and motor carriers unchanged. Both would benefit from the expansion of terminal areas. The motor carrier might suffer slightly because the forwarder will be able to utilize his own vehicles for assembly and distribution service within a greater area; on the other hand, if the forwarder can operate his own vehicles profitably in this service, the motor carrier ought to be able to provide the service under contract rates even within the terminal area, and still profit from it. ${ }^{145}$

It will probably be necessary for Congress to erase the distinction between surface forwarder terminal areas and air cargo ground transportation incidental to transportation by aircraft. At present, only the ICC, with its exclusive jurisdiction over motor carrier transportation, can change terminal area definitions. But the ICC is prone to restrict the scope of motor vehicle operations by non-motor carriers; and if it refuses to adapt to intermodal forwarding, authority to determine the size of indirect carrier terminal areas should be given to the interagency joint board proposed above. ${ }^{146}$

145. Surface forwarders in recent years have complained that the long-haul motor carriers are buying up local motor carriers and then (it is said) refusing to grant section 409 rates to the forwarders in order to capture more traffic for motor carricr less-than-truckload service. See 1963 Freight Forwarder Acquisition Hearings 17. The cxpansion of the terminal areas of freight forwarders should ameliorate this difficulty if it is in fact scrious. 146. See pp. 1377, 1386 supra. 